\title{
Perancangan Alat Pengendali Pintu Air Sawah Otomatis dengan SIM800I Berbasis Mikrokontroler Arduino Uno
}

\author{
I Putu Lingga Dharma 1), Salmawaty Tansa 2), Iskandar Zulkarnain Nasibu ${ }^{3)}$ \\ 1),2),3) Jurusan Teknik Elektro, Fakultas Teknik, Universitas Negeri Gorontalo \\ e-mail: linggadharma@gmail.com
}

\begin{abstract}
Abstrak
Pertanian merupakan sumber mata pencarian utama penduduk Indonesia yang tinggal di daerah pedesaan. Salah satunya padi sawah. Umumnya, untuk mengelola sawah, petani mengunjungi lahan pertanian untuk melihat kondisi tanah pada sawah secara periodik dan mengairi lahan pertanian dengan membuka dan menutup saluran irigasi sesuai dengan perspektif petani. Hasil padi sawah dipengaruhi oleh banyak faktor antara lain, iklim yang selalu berubah, ketersediaan air, kesuburan tanah, sistem pengelolaan tanaman dan lain sebagainya. Sehingga diperlukan suatu sistem yang dapat mengendalikan pendistribusian air secara merata dan cukup. Pada penelitian ini bertujuan untuk membuat model alat pengendali pintu air sawah otomatis dengan Sim800L berbasis mikrokontroler arduino uno. Dalam bentuk model alat ini mampu memberikan alternatif dalam memudahkan petani melakukan pengontrolan air pada lahan persawahan. Metode yang digunakan dalam penelitian ini yaitu metode rancang bangun model alat yang terdiri dari beberapa tahap yaitu: penentuan spesifikasi alat, diagram blok alat, perancangan alat dan pengujian alat. Perancangan alat ini terdiri dari perancangan perangkat keras dan perangkat lunak dengan mikrokontroler ATmega 328 pada arduino uno sebagai kontrol utama dalam sistem yang ada. Hasil dari pembuatan model alat ini yaitu berupa kendali pintu air sawah secara otomatis dengan Sim800I berrbasis mikrokontroler ATmega 328 pada arduino uno yang dapat bekerja dengan baik sesuai dengan spesifikasi yang diharapkan.
\end{abstract}

Kata Kunci: arduino uno, buka tutup pintu sawah, Sim800L, mikrokontroler ATmega 328.

\section{Pendahuluan}

Pertanian merupakan sumber mata pencarian utama penduduk Indonesia yang tinggal didaerah pedesaan. Lahan - lahan yang luas dimanfaatkan oleh penduduk desa untuk dijadikan persawahan. Hasil padi sawah dipengaruhi oleh banyak faktor antaranya, iklim yang selalu berubah, ketersediaan air, kesuburan tanah, varietas, sistem pengolahan tanaman dan perkembangan hama dan penyakit.

Pertumbuhan dan perkembangan tanaman bisa terganggu karena kebutuhan air pada tanaman tidak tercukupi atau keberadaan air yang berlebihan. Dalam penyediaan kebutuhan air untuk tanaman dapat dilakukan dengan sistem irigasi. Pada umumnya, petani mengunjungi lahan pertanian untuk melihat kondisi lahan pada sawah secara periodik dan mengaliri air dengan membuka dan menutup saluran irigasi sesuai dengan perspektif petani itu sendiri. sehingga perlunya suatu sistem yang dapat mengendalikan pendistribusian air secara merata dan cukup pada lahan. 
Dengan perkembangan teknologi, penulis kembangkan suatu sistem pengendali pintu air sawah secara otomatis. Kelebihan dalam alat ini yaitu dapat memantau kondisi tinggi air serta mengendalikan pintu air dengan bantuan mikrokontroler arduino uno ATmega 328 dan memberikan notifikasi melalui SMS.

\section{Irigasi}

Peraturan pemerintah (PP) 20/2006 tentang irigasi menyatakan Irigasi adalah usaha penyediaan, pengaturan, dan pembuangan air irigasi untuk menunjang pertanian. Penyediaan air irigasi adalah penentuan volume air per satuan waktu yang dialokasikan dari suatu sumber air untuk suatu daerah irigasi yang didasarkan waktu, jumlah, dan mutu sesuai dengan kebutuhan untuk menunjang pertanian dan keperluan lainnya.

\section{Mikrokontroler ATmega 328}

ATmega328 adalah mikrokontroler keluaran dari atmel yang mempunyai arsitektur Reduce Instruction Set Computer (RISC) dimana setiap proses eksekusi data lebih cepat dari pada arsitektur Completed Instruction Set Computer(CISC). Mikrokontroller ini memiliki beberapa fitur antara lain (Ramakumbo, 2012).
a. 130 macam instruksi yang hampir dieksekusi dalam satu siklus clock.
b. $32 \times 8$-bit register serba guna.
C. Kecepatan mencapai 16 MIPS dengan clock $16 \mathrm{MHz}$.
d. $32 \mathrm{~KB}$ Flash memory dan pada arduino memiliki bootloader yang menggunakan $2 \mathrm{~KB}$ dari flash memori sebagai bootloader.
e. Memiliki EEPROM (Electrically Erasable Programmable Read Only Memory) sebesar $1 \mathrm{~KB}$ sebagai tempat penyimpanan data semi permanent karena EEPROM tetap dapat menyimpan data meskipun catu daya dimatikan.

f. Memiliki SRAM (Static Random Access Memory) sebesar 2KB.
g. Memiliki pin I/O digital sebanyak 14 pin 6 diantaranya PWM (Pulse Width Modulation) output.
h. Master / Slave SPI Serial interface. ATmega328 yang terdapat dalam mikrokontroler arduino uno memiliki bentuk fisik seperti yang terdapat pada

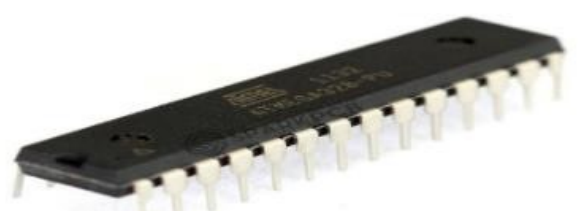

\section{Gambar 1. Bentuk fisik ATmega 328}

Gambar 1 dengan susunan konfigurasi pin Atmega328 terdapat pada Gambar 2 


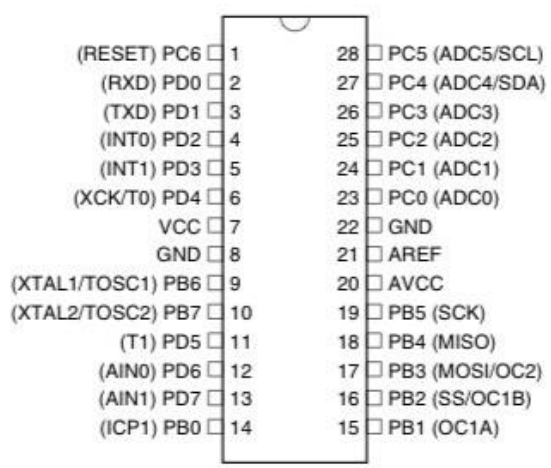

Gambar 2. Konfigurasi pin ATmega328

\section{Arduino Uno}

Arduino merupakan sebuah board minimum system mikrokontroller yang bersifat open source. Bentuk fisik arduino terdapat pada Gambar 2. Didalam rangkaian board arduino terdapat mikrokontroller AVR seri 328 yang merupakan produk dari Atmel. Arduino memiliki kelebihan tersendiri dibanding board mikrokontroller yang lain selain bersifat open source, arduino juga mempunyai bahasa programnya sendiri berupa bahasa C. selain itu dalam board arduino sendiri sudah terdapat loader yang berupa USB sehingga memudahkan ketika diprogram mikrokontroller didalam arduino (www.arduino.cc)

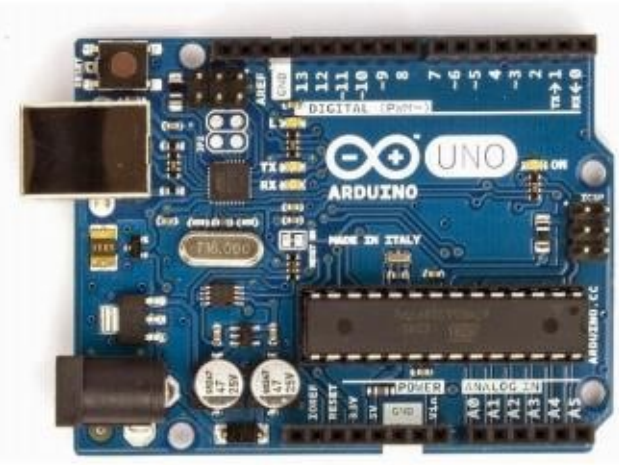

\section{Sensor Air}

Gambar 3. Arduino Uno

Sensor adalah alat untuk mendeteksi/mengukur sesuatu yang digunakan untuk mengubah variasi mekanis, magnetis, panas, sinar dan kimia menjadi tegangan dan arus listrik. Dalam lingkungan sistem pengendali dan robotika, sensor memberikan kesamaan yang menyerupai mata, pendengaran, hidung, lidah yang kemudian akan diolah oleh kontroler sebagai otaknya (Cahyo, 2011).

Pada penelitian ini, sensor yang digunakan berupa kabel tembaga yang dirangkai dengan resistor serta output tegangan terhubung pada mikrokontroler arduino uno. 
Tegangan output dari sensor akan diubah menjadi data input pada mikrokontroler dengan sistem ADC yang terdapat pada arduino uno.

Analog To Digital Converter (ADC) adalah pengubah input analog menjadi kode - kode digital. Dalam pembacaan tegangan analog yang masuk pada pin analog Arduino, tegangan yang masuk dikonversi terlebih dahulu menjadi data digital. Arduino yang digunakan adalah Arduino UNO. Pin analog Arduino dapat menerima nilai hingga 10 bit sehingga dapat mengkonversi data analog menjadi 1024 keadaan $\left(2^{\wedge} 10=1024\right)$.

Rumus konversi nilai analog yang terbaca diubah dalam bentuk digital sebagai berikut ini :

$$
\mathrm{ADC}=\frac{V_{\text {in } \times 2^{10}}}{V_{\text {ref }}}
$$

Keterangan :

$\mathrm{V}_{\text {ref }} \quad=$ Tegangan Referensi (Volt)

$V_{\text {in }} \quad=$ Tegangan input analog (Volt)

$\mathrm{ADC}=$ nilai digital

\section{SIM 800L GSM/GPRS}

Modul SIM800L GSM/GPRS adalah bagian yang berfungsi untuk berkomunikasi antara pemantau utama dengan Handphone. AT Command adalah perintah yang dapat diberikan modem GSM/CDMA seperti untuk mengirim dan menerima data berbasis GSM/GPRS, atau mengirim dan menerima SMS. SIM800LGSM/GPRS dikendalikan melalui perintah AT dengan bentuk fisik seperti Gambar 4.

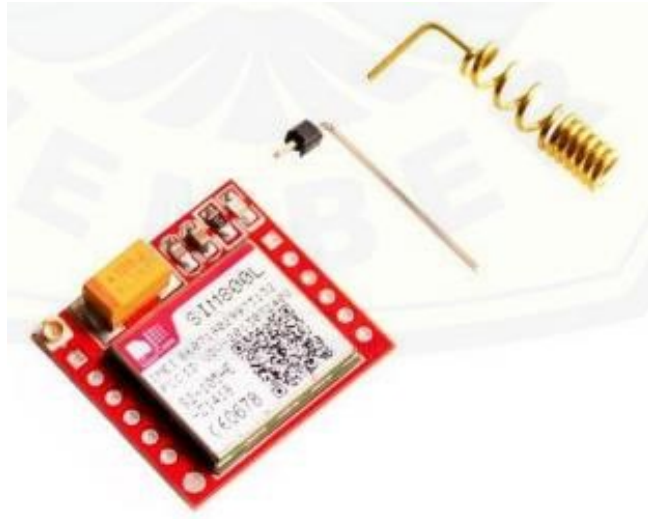

Gambar 4. SIM800L

\section{SMS (Short Message Service)}

SMS Gateway adalah komunikasi menggunakan SMS yang mengandung informasi berupa nomor telepon seluler pengirim, penerima, waktu dan pesan. Informasi 
tersebut dapat diolah dan bisa melakukan aktivasi transaksi tergantung kode-kode yang sudah disepakati. Untuk dapat mengelola semua transaksi yang masuk dibutuhkan sebuah sistem yang mampu menerima kode SMS dengan jumlah tertentu, mengolah informasi yang terkandung dalam pesan SMS dan melakukan transaksi yang dibutuhkan. SMS Gateway biasanya support untuk pesan yang berupa teks, unicode character, dan juga smart messaging ringtone, picture message, logo operator dan lainlain. (Afrina,2015).

\section{LCD (Liquid Cristal Display)}

Display elektronik adalah satu komponen elektronika yang berfungsi sebagai tampilan suatu data, baik karakter, huruf ataupun grafik. LCD (Liquid Cristal Display) adalah salah satu jenis display elektronik yang dibuat dengan teknologi CMOS logic yang bekerja dengan tidak menghasilkan cahaya tetapi memantulkan cahaya yang ada di sekelilingnya terhadap front-lit atau mentransmisikan cahaya dari back-lit. Bentuk fisik dari LCD 2x16 dapat dilihat pada Gambar 5 (Ridwan, 2016).

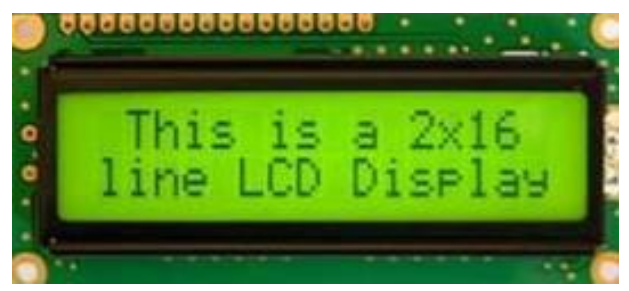

Gambar 5. LCD 16x2

\section{Motor Servo}

Motor servo adalah sebuah perangkat atau aktuator putar (motor) yang dirancang dengan sistem kontrol umpan balik loop tertutup (servo), sehingga dapat di set-up atau di atur untuk menentukan dan memastikan posisi sudut dari poros output motor. Bentuk fisik motor servo dilihat pada Gambar 6 (Syahrul, 2011).

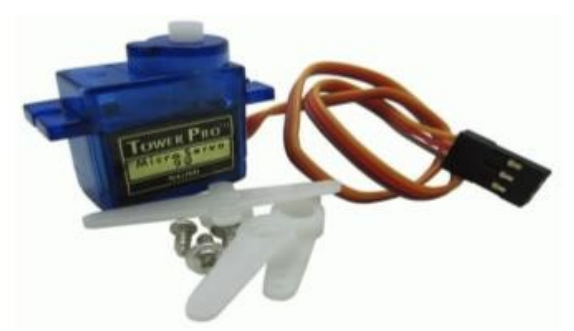

Gambar 6. Motor Servo

\section{Arduino IDE (Integrated Development Environment)}

Arduino memiliki open-source yang memudahkan untuk menulis kode dan mengupload board ke arduino. Arduino IDE (Integrated Development Enviroment) ini merupakan media yang digunakan untuk memberikan informasi kepada arduino 
sehingga dapat memberikan output sesuai dengan apa yang diinginkan. Software arduino yaitu berupa software processing yang digunakan untuk menulis program kedalam Arduino Uno, merupakan penggabungan antara bahasa $\mathrm{C}++$ dan Java. Software Arduino dapat di-install di berbagai operating sistem seperti Linux, Mac OS, Windows (Mulyana.,dkk (2014)). IDE (Integrated Development Enviroment) arduino merupakan pemograman dengan mengggunakan bahasa C. Setiap program IDE arduino yang biasa disebut sketch Interface Arduino IDE tampak seperti gambar 7 .

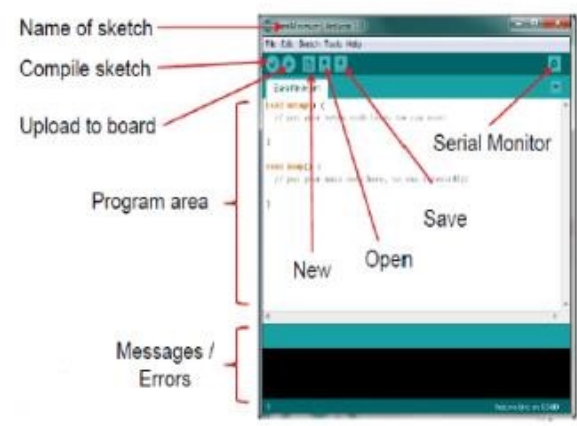

Gambar 7. Interface arduino IDE

\section{Converter DC to DC}

Konverter LM2596 DC to Dc Step Down merupakan penurun tegangan yang mengkonversi tegangan masukan DC menjadi DC lainnya yang lebih rendah, bentuk fisik modul converter tegangan dc to dc dilihat pada Gambar 8 (Faiz Abdurrahman, 2016).

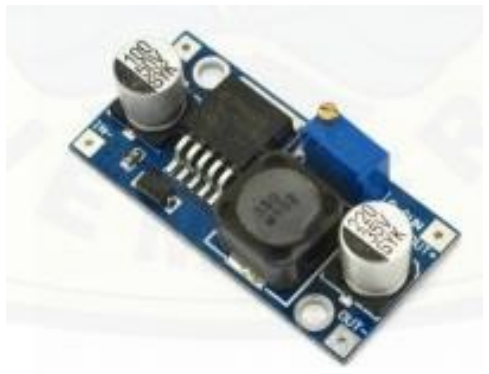

Gambar 8. Modul Converter Dc to Dc

\section{Resistor}

Tahanan listrik dalam bidang elektronika disebut dengan resistor atau resistance, dalam bahasa belanda disebut dengan nama Werstand. Tahanan listrik adalah suatu komponen yang dapat menghambat arus listrik pada suatu penghantar. Besar kecilnya nilai tahanan dapat dinyatakan dengan satuan ohm atau ditulis dengan huruf latin $\Omega$ (omega) dan notasi ditulis dengan huruf R. Bentuk fisik resistor dapat dilihat pada Gambar 9 (Rusmanadi, 2009). 


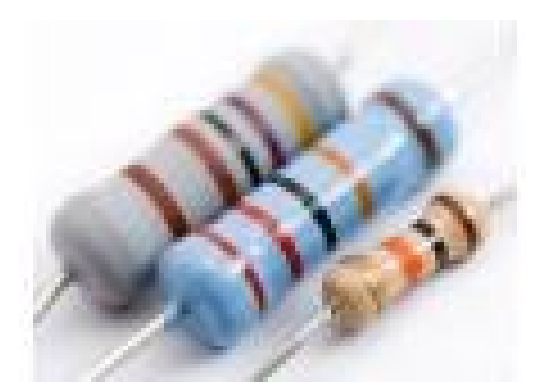

Gambar 9. Bentuk fisik resistor

Resistor bekerja dengan Hukum Ohm yang diformulasikan sebagai persamaan berikut :

$$
\begin{gathered}
\mathrm{V}=\mathrm{I} \times \mathrm{R} \\
\mathrm{I}=\frac{V}{R}
\end{gathered}
$$

Keterangan :

$\mathrm{V} \quad=$ tegangan listrik (Volt)

$\mathrm{I}=$ Arus (Ampere)

$\mathrm{R}=$ Hambatan (Ohm)

Rumus resisitor sebagai pembagi tegangan diformulasikan dalam persamaan sebagai berikut :

$$
\mathrm{V}_{\text {out }}=\mathrm{V}_{\mathrm{R} 2}
$$

Persamaan 3.3 diturunkan menjadi :

$$
\mathrm{V}_{\text {out }}=\mathrm{I}_{\mathrm{R} 2} \times \mathrm{R}_{2}
$$

Persamaan 3.4 diturunkan menjadi :

$$
\mathrm{V}_{\text {out }}=\frac{V_{i}}{R_{1}+R_{2}} \times \mathrm{R}_{2}
$$

\section{Metode}

\section{Metode Penelitian}

Metode penelitian yang digunakan dalam penelitian tugas akhir ini adalah sebagai berikut :

\section{a. Studi Pustaka}

Pada metode ini penulis akan melakukan pencarian informasi tentang penelitian dari berbagai macam sumber baik berupa buku, jurnal, internet dan dokumen lainnya yang menunjang pengerjaan yang berkaitan dengan penelitian yang dilakukan penulis.

b. Eksperimen 
Pada metode ini, penulis melakukan percobaan secara langsung dalam pembuatan alat dan pengujian input, proses serta output, sehingga pengoperasian alat dapat dilakukan secara normal.

\section{Lokasi Penelitian}

Lokasi pelaksanaan pembuatan alat ini yaitu dikota Gorontalo dan Laboraturium Teknik Listrik Jurusan Teknik Elektro Fakultas Teknik Universitas Negeri Gorontalo

\section{Alat dan bahan Penelitian}

Alat dan bahan yang digunakan dalam penelitian ini adalah sebagai berikut:

a. Alat

- Leptop (Hardware)

- Arduino Software IDE (Software)

- Aplikasi Fritzing (Software)

- Multimeter

- Solder

\section{b. Bahan}

- Arduino uno ATmega 328

- SIM 800L GSM/GPRS

- LCD ( Liquid Cristal Display)

- $\quad$ I2C interface

- Motor Servo

- Converter DC to DC

- Power Suplay

- Kabel Jumper

- Kabel Tembaga

- Resistor $33 \mathrm{k} \Omega$

- Akrilik

- Relay

- Pompa Air

\section{Perancangan Alat}

Tahap perancangan alat sebagai berikut :

\section{a. Diagram Blok Alat}

Diagram blok dibuat dengan susunan yang disajikan pada Gambar 10 sebagai berikut: 


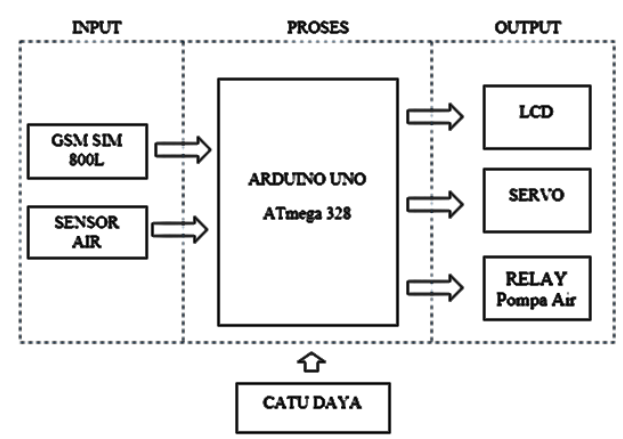

Gambar 10. Diagram Blok

\section{b. Perancangan Perangkat Keras}

Perancangan perangkat keras dilakukan dengan cara menghubungkan masing masing komponen dengan mikrokontroler yang digunakan pada alat kendali pintu air sawah secara otomatis sehingga alat dapat dioprasikan sesuai dengan fungsinya. Rangkaian pada Gambar 11 merupakan rangkaian keseluruhan komponen yang bekerja saling berhubungan dan saling berkomunikasi.

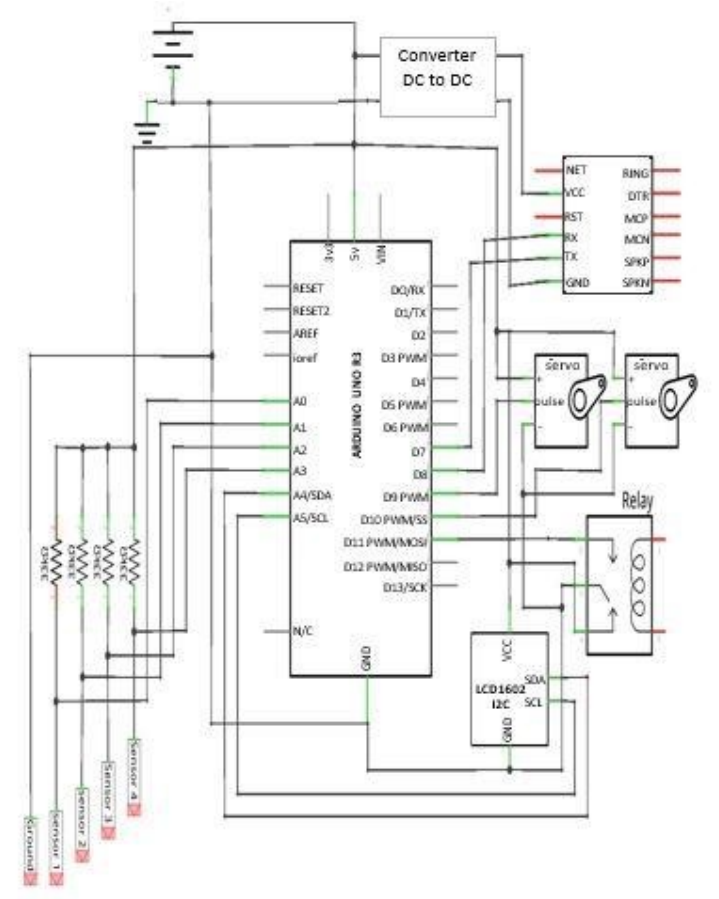

Gambar 11. Rangkaian Keseluruhan komponen

\section{c. Perancangan Perangkat Lunak}

Dalam perancangan perangkat lunak akan ditunjukkan dengan diagram alir/flowchart sesuai dengan perintah yang diberikan mikrokontroler serta komponen yang digunakan . Tahapan perancangan perangkat lunak dilihat pada Gambar 12. 


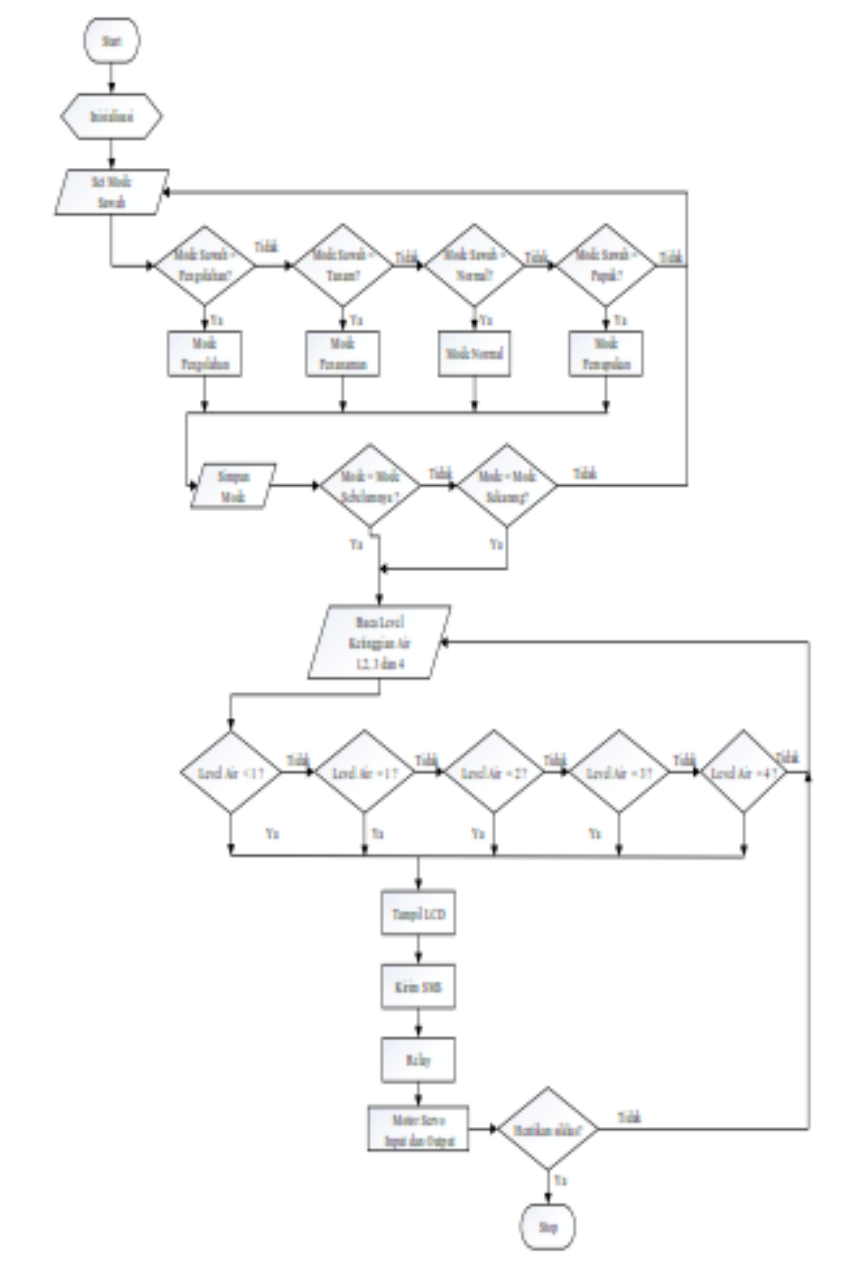

Gambar 12. Flowchart Perancangan Program Alat

\section{Hasil Dan Pembahasan}

\section{Hasil Perancangan Model Alat}

Dalam pengujian skema rangkaian keseluruhan alat ini bertujuan untuk dapat mengetahuai pengontrolan/pengendalian keseluruhan komponen yang digunakan. Hasil perancangan alat ini diharapkan dapat berjalan dengan baik. Setelah melewati proses perancangan sistem baik dari segi perangkat keras maupun perangkat lunak. maka hasil perancangan model alat utama secara keseluruhan dapat dilihat pada Gambar 13.

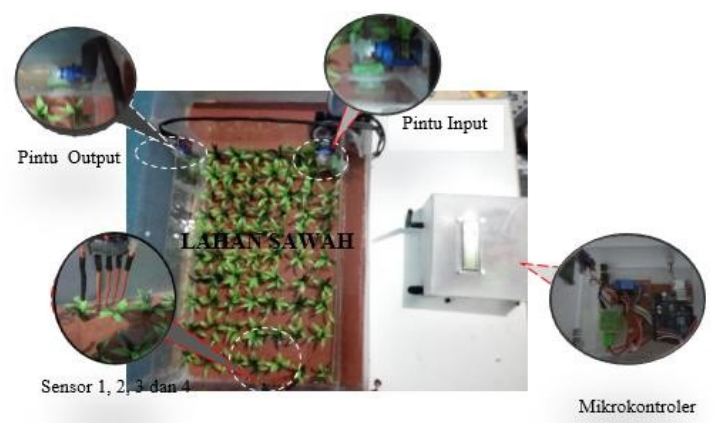

Gambar 13. Model alat kendali pintu air sawah otomatis 


\section{Analisis Hasil Sensor Air}

Dalam hasil pengukuran yang diperoleh penulis dengan hasil perhitungan yang dilakukan disajikan dalam Tabel sebagai berikut:

Tabel 2. Hasil nilai perbandingan

\begin{tabular}{|c|l|c|c|c|c|}
\hline \multirow{2}{*}{ No } & \multirow{2}{*}{ Sensor } & \multicolumn{2}{|c|}{ Resistor } & \multicolumn{2}{c|}{ Pengukuran } \\
\cline { 3 - 6 } & & R1 & R2 & Pengukuran & Perhitungan \\
\hline 1 & Sensor 1 & $33 \mathrm{~K} \Omega$ & $15 \mathrm{~K} \Omega$ & 1,792 Volt & 1,5625 Volt \\
\hline 2 & Sensor 2 & $33 \mathrm{~K} \Omega$ & $15 \mathrm{~K} \Omega$ & 1,866 Volt & 1,5625 Volt \\
\hline 3 & Sensor 3 & $33 \mathrm{~K} \Omega$ & $15 \mathrm{~K} \Omega$ & 1,849 Volt & 1,5625 Volt \\
\hline 4 & Sensor 4 & $33 \mathrm{~K} \Omega$ & $15 \mathrm{~K} \Omega$ & 1,747 Volt & 1,5625 Volt \\
\hline
\end{tabular}

Hasil yang diperoleh diatas, diubah kedalam bentuk digital dengan menggunakan persamaan 2.1 yang diperoleh hasil sebagai berikut.

Tabel 3. Hasil nilai perbandingan ADC

\begin{tabular}{|l|c|c|c|c|c|}
\hline \multirow{2}{*}{ No } & \multirow{2}{*}{ Sensor } & \multicolumn{4}{|c|}{ Nilai ADC (Desimal) } \\
\cline { 3 - 6 } & & \multicolumn{2}{|c|}{ Pengukuran } & \multicolumn{2}{c|}{ Perhitungan } \\
\cline { 3 - 6 } & & Desimal & Biner & Desimal & Biner \\
\hline 1 & Sensor 1 & 367 & 101101111 & 320 & 101000000 \\
\hline 2 & Sensor 2 & 382 & 101111110 & 320 & 101000000 \\
\hline 3 & Sensor 3 & 378 & 101111010 & 320 & 101000000 \\
\hline 4 & Sensor 4 & 357 & 101100101 & 320 & 101000000 \\
\hline
\end{tabular}

\section{Hasil Pengujian Mode Alat}

Pada model alat dalam penelitian ini terdapat 4 mode input yang menjadi pedoman dalam pengontrolan kondisi pada lahan sawah. Perintah penginputan mode dilakukan melalui sms yang dikirim oleh petani/ user.Hasil pengujian sebagai berikut:

\section{a. Hasil Pengujian Mode Pengolahan}

Mode pengolahan merupakan pengaturan tinggi air yang diperlukan petani pada saat melakukan proses pengolahan. Pada mode ini, kondisi air diatur untuk mencapai sensor level 3 sebagai acuan level ketinggian air. Jika pada saat tertentu level air melebihi batas ketinggian, maka air akan di keluarkan melalui pintu output pada lahan persawahan. Hasil pengujian mode pengolahan terdapat pada tabel 4 . 
Tabel 4. Hasil pengujian mode pengolahan

\begin{tabular}{|c|c|c|c|c|c|c|c|}
\hline \multirow{2}{*}{ Mode } & \multicolumn{4}{|c|}{ Input } & \multicolumn{2}{|c|}{ Output } & \multirow{2}{*}{$\begin{array}{l}\text { Kondisi } \\
\text { Lahan }\end{array}$} \\
\hline & $\begin{array}{c}\text { Sensor } \\
4\end{array}$ & $\begin{array}{c}\text { Sensor } \\
\mathbf{3}\end{array}$ & $\begin{array}{c}\text { Sensor } \\
2\end{array}$ & $\begin{array}{c}\text { Sensor } \\
1\end{array}$ & $\begin{array}{l}\text { Pintu } \\
\text { Input }\end{array}$ & $\begin{array}{c}\text { Pintu } \\
\text { Output }\end{array}$ & \\
\hline \multirow{16}{*}{ Pengolahan } & 0 & 0 & 0 & 0 & Terbuka & Tertutup & $\begin{array}{c}\text { Kekurangan } \\
\text { Air }\end{array}$ \\
\hline & 0 & 0 & 0 & 1 & Terbuka & Tertutup & $\begin{array}{c}\text { Kekurangan } \\
\text { Air }\end{array}$ \\
\hline & 0 & 0 & 1 & 0 & $\mathrm{x}$ & $\mathrm{x}$ & $\mathrm{x}$ \\
\hline & 0 & 0 & 1 & 1 & Terbuka & Tertutup & $\begin{array}{c}\text { Kekurangan } \\
\text { Air }\end{array}$ \\
\hline & 0 & 1 & 0 & 0 & $\mathrm{x}$ & $\mathrm{x}$ & $\mathrm{x}$ \\
\hline & 0 & 1 & 0 & 1 & $\mathrm{x}$ & $\mathrm{x}$ & $\mathrm{x}$ \\
\hline & 0 & 1 & 1 & 0 & $\mathrm{x}$ & $\mathrm{x}$ & $\mathrm{x}$ \\
\hline & 0 & 1 & 1 & 1 & Tertutup & Tertutup & Cukup Air \\
\hline & 1 & 0 & 0 & 0 & $\mathrm{x}$ & $\mathrm{x}$ & $\mathrm{x}$ \\
\hline & 1 & 0 & 0 & 1 & $\mathrm{x}$ & $\mathrm{x}$ & $\mathrm{x}$ \\
\hline & 1 & 0 & 1 & 0 & $\mathrm{x}$ & $\mathrm{x}$ & $\mathrm{x}$ \\
\hline & 1 & 0 & 1 & 1 & $\mathrm{x}$ & $\mathrm{x}$ & $\mathrm{x}$ \\
\hline & 1 & 1 & 0 & 0 & $\mathrm{x}$ & $\mathrm{x}$ & $\mathrm{x}$ \\
\hline & 1 & 1 & 0 & 1 & $\mathrm{x}$ & $\mathrm{x}$ & $\mathrm{x}$ \\
\hline & 1 & 1 & 1 & 0 & $\mathrm{x}$ & $\mathrm{x}$ & $\mathrm{x}$ \\
\hline & 1 & 1 & 1 & 1 & Tertutup & Terbuka & $\begin{array}{c}\text { Kelebihan } \\
\text { Air }\end{array}$ \\
\hline
\end{tabular}

\section{b. Hasil Pengujian Mode Penanaman}

Mode penanaman merupakan pengaturan kondisi lahan dengan level ketinggian air kurang dari sensor 2, 3 dan 4. Mode penanaman digunakan dalam proses petani melakukan cocok tanam pada lahan pertanian / sawah. Pada mode ini, air yang dibutuhkan tidak terlalu banyak sehingga jika level ketinggian air melebihi sensor 1 maka air yang ada akan dikeluarkan melalui pintu output sampai level air pada kondisi tidak sama dengan Sensor 2, 3 atau 4. Pada saat air tidak melebihi dan kurang dari kondisi sensor 1, mikrokontroler akan membaca kondisi lahan terpenuhi. . Hasil pengujian pada mode penanaman terdapat pada Tabel 5.

Tabel 5. Hasil pengujian mode penanaman

\begin{tabular}{|c|c|c|c|c|c|c|c|}
\hline \multirow{2}{*}{ Mode } & \multicolumn{4}{|c|}{ Input } & \multicolumn{2}{|c|}{ Output } & \multirow{2}{*}{$\begin{array}{l}\text { Kondisi } \\
\text { Lahan }\end{array}$} \\
\hline & $\begin{array}{c}\text { Sensor } \\
4\end{array}$ & $\begin{array}{c}\text { Sensor } \\
3\end{array}$ & $\begin{array}{c}\text { Sensor } \\
\mathbf{2}\end{array}$ & $\begin{array}{c}\text { Sensor } \\
1\end{array}$ & $\begin{array}{l}\text { Pintu } \\
\text { Input }\end{array}$ & $\begin{array}{c}\text { Pintu } \\
\text { Output }\end{array}$ & \\
\hline \multirow{16}{*}{ Penanaman } & 0 & 0 & 0 & 0 & Tertutup & Tertutup & Cukup Air \\
\hline & 0 & 0 & 0 & 1 & Tertutup & Tertutup & Cukup Air \\
\hline & 0 & 0 & 1 & 0 & $\mathrm{x}$ & $\mathrm{x}$ & 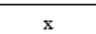 \\
\hline & 0 & 0 & 1 & 1 & Tertutup & Terbuka & $\begin{array}{c}\begin{array}{c}\text { Kelebihan } \\
\text { Air }\end{array} \\
\end{array}$ \\
\hline & 0 & 1 & 0 & 0 & $\mathrm{x}$ & $\mathrm{x}$ & $\mathrm{x}$ \\
\hline & 0 & 1 & 0 & 1 & $\mathrm{x}$ & $\mathrm{x}$ & $\mathrm{x}$ \\
\hline & 0 & 1 & 1 & 0 & $\mathrm{x}$ & $\mathrm{x}$ & $\mathrm{x}$ \\
\hline & 0 & 1 & 1 & 1 & Tertutup & Terbuka & $\begin{array}{c}\text { Kelebihan } \\
\text { Air }\end{array}$ \\
\hline & 1 & 0 & 0 & 0 & $\mathrm{x}$ & $\mathrm{x}$ & $\mathrm{x}$ \\
\hline & 1 & 0 & 0 & 1 & $\mathrm{x}$ & $\mathrm{x}$ & $\mathrm{x}$ \\
\hline & 1 & 0 & 1 & 0 & $\mathrm{x}$ & $\mathrm{x}$ & $\mathrm{x}$ \\
\hline & 1 & 0 & 1 & 1 & $\mathrm{x}$ & $\mathrm{x}$ & $\mathrm{x}$ \\
\hline & 1 & 1 & 0 & 0 & $\mathrm{x}$ & $\mathrm{x}$ & $\mathrm{x}$ \\
\hline & 1 & 1 & 0 & 1 & $\mathrm{x}$ & $\mathrm{x}$ & $\mathrm{x}$ \\
\hline & 1 & 1 & 1 & 0 & $\mathrm{x}$ & $\mathrm{x}$ & $\mathrm{x}$ \\
\hline & 1 & 1 & 1 & 1 & Tertutup & Terbuka & $\begin{array}{c}\begin{array}{c}\text { Kelebihan } \\
\text { Air }\end{array} \\
\end{array}$ \\
\hline
\end{tabular}




\section{c. Hasil Pengujian Mode Normal}

Mode Normal berfungsi untuk menetapkan kondisi lahan dalam genangan air yang tidak berlebihan. Mode ini mengatur level ketinggian air pada sensor 3 terpenuhi atau level ketinggian air pada Sensor 3. Pada mode ini, jika air yang terdapat pada lahan kurang dari level yang ditentukan maka pintu input akan terbuka sehingga air akan memasuki lahan pertanian sampai level ketinggian terpenuhi. Sebaliknya jika ketinggian air melebihi level yang ditentukan, maka pintu output akan terbuka sampai level ketinggian sensor 3 terpenuhi. Hasil pengujian pada mode normal terdapat pada Tabel 6 .

Tabel 6. Hasil pengujian mode normal

\begin{tabular}{|c|c|c|c|c|c|c|c|}
\hline \multirow{2}{*}{ Mode } & \multicolumn{4}{|c|}{ Input } & \multicolumn{2}{|c|}{ Output } & \multirow{2}{*}{$\begin{array}{l}\text { Kondisi } \\
\text { Lahan }\end{array}$} \\
\hline & $\begin{array}{c}\text { Sensor } \\
\mathbf{4}\end{array}$ & $\begin{array}{c}\text { Sensor } \\
\mathbf{3}\end{array}$ & $\begin{array}{c}\text { Sensor } \\
\mathbf{2}\end{array}$ & $\begin{array}{c}\text { Sensor } \\
1\end{array}$ & $\begin{array}{l}\text { Pintu } \\
\text { Input }\end{array}$ & $\begin{array}{l}\text { Pintu } \\
\text { Output }\end{array}$ & \\
\hline \multirow{16}{*}{ Normal } & 0 & 0 & 0 & 0 & Terbuka & Tertutup & $\begin{array}{c}\text { Kekurangan } \\
\text { Air }\end{array}$ \\
\hline & 0 & 0 & 0 & 1 & Terbuka & Tertutup & $\begin{array}{c}\text { Kekurangan } \\
\text { Air }\end{array}$ \\
\hline & 0 & 0 & 1 & 0 & $\mathrm{x}$ & $\mathrm{x}$ & $\mathrm{x}$ \\
\hline & 0 & 0 & 1 & 1 & Terbuka & Tertutup & $\begin{array}{c}\text { Kekurangan } \\
\text { Air }\end{array}$ \\
\hline & 0 & 1 & 0 & 0 & $\mathrm{x}$ & $\mathrm{x}$ & $\mathrm{x}$ \\
\hline & 0 & 1 & 0 & 1 & $\mathrm{x}$ & $\mathrm{x}$ & $\mathrm{x}$ \\
\hline & 0 & 1 & 1 & 0 & $\mathrm{x}$ & $\mathrm{x}$ & $\mathrm{x}$ \\
\hline & 0 & 1 & 1 & 1 & Tertutup & Tertutup & Cukup Air \\
\hline & 1 & 0 & 0 & 0 & $\mathrm{x}$ & $\mathrm{x}$ & $\mathrm{x}$ \\
\hline & 1 & 0 & 0 & 1 & $\mathrm{x}$ & $\mathrm{x}$ & $\mathrm{x}$ \\
\hline & 1 & 0 & 1 & 0 & $\mathrm{x}$ & $\mathrm{x}$ & $\mathrm{x}$ \\
\hline & 1 & 0 & 1 & 1 & $\mathrm{x}$ & $\mathrm{x}$ & $\mathrm{x}$ \\
\hline & 1 & 1 & 0 & 0 & $\mathrm{x}$ & $\mathrm{x}$ & $\mathrm{x}$ \\
\hline & 1 & 1 & 0 & 1 & $\mathrm{x}$ & $\mathrm{x}$ & $\mathrm{x}$ \\
\hline & 1 & 1 & 1 & 0 & $\mathrm{x}$ & $\mathrm{x}$ & $\mathrm{x}$ \\
\hline & 1 & 1 & 1 & 1 & Tertutup & Terbuka & $\begin{array}{c}\text { Kelebihan } \\
\text { Air }\end{array}$ \\
\hline
\end{tabular}

\section{d. Hasil pengujian Mode Pupuk}

Mode pemupukan berfungsi untuk menetapkan kondisi lahan dalam keaadaan genangan dangkal dan berlumpur. Mode ini menentapkan kondisi air yang tidak berlebihan dan tidak membajir lahan yang akan di pupuk. Pada mode ini, jika air yang terdapat pada lahan melebihi kondisi yang ditentukan maka pintu output yang terdapat pada lahan akan terbuka dan mengeluarkan air sampai kondisi level terpenuhi. Hasil pengujian pada mode pemupukan terdapat pada Tabel 7. 
Tabel 7. Hasil pengujian mode pemupukan

\begin{tabular}{|c|c|c|c|c|c|c|c|}
\hline \multirow{2}{*}{ Mode } & \multicolumn{4}{|c|}{ Input } & \multicolumn{2}{|c|}{ Output } & \multirow{2}{*}{$\begin{array}{l}\text { Kondisi } \\
\text { Lahan }\end{array}$} \\
\hline & $\begin{array}{c}\text { Sensor } \\
4\end{array}$ & $\begin{array}{c}\text { Sensor } \\
\mathbf{3}\end{array}$ & $\begin{array}{c}\text { Sensor } \\
\mathbf{2}\end{array}$ & $\begin{array}{c}\text { Sensor } \\
1\end{array}$ & $\begin{array}{l}\text { Pintu } \\
\text { Input }\end{array}$ & $\begin{array}{c}\text { Pintu } \\
\text { Output }\end{array}$ & \\
\hline \multirow{16}{*}{ Pemupukan } & 0 & 0 & 0 & 0 & Tertutup & Tertutup & Cukup Air \\
\hline & 0 & 0 & 0 & 1 & Tertutup & Tertutup & Cukup Air \\
\hline & 0 & 0 & 1 & 0 & $\mathrm{x}$ & $\mathrm{x}$ & $\mathrm{x}$ \\
\hline & 0 & 0 & 1 & 1 & Tertutup & Terbuka & $\begin{array}{l}\text { Kelebihan } \\
\text { Air }\end{array}$ \\
\hline & 0 & 1 & 0 & 0 & $\mathrm{x}$ & $\mathrm{x}$ & $\mathrm{x}$ \\
\hline & 0 & 1 & 0 & 1 & $\mathrm{x}$ & $\mathrm{x}$ & $\mathrm{x}$ \\
\hline & 0 & 1 & 1 & 0 & $\mathrm{x}$ & $\mathrm{x}$ & $\mathrm{x}$ \\
\hline & 0 & 1 & 1 & 1 & Tertutup & Terbuka & $\begin{array}{l}\text { Kelebihan } \\
\text { Air }\end{array}$ \\
\hline & 1 & 0 & 0 & 0 & $\mathrm{x}$ & $\mathrm{x}$ & $\mathrm{x}$ \\
\hline & 1 & 0 & 0 & 1 & $\mathrm{x}$ & $\mathrm{x}$ & $\mathrm{x}$ \\
\hline & 1 & 0 & 1 & 0 & $\mathrm{x}$ & $\mathrm{x}$ & $\mathrm{x}$ \\
\hline & 1 & 0 & 1 & 1 & $\mathrm{x}$ & $\mathrm{x}$ & $\mathrm{x}$ \\
\hline & 1 & 1 & 0 & 0 & $\mathrm{x}$ & $\mathrm{x}$ & $\mathrm{x}$ \\
\hline & 1 & 1 & 0 & 1 & $\mathrm{x}$ & $\mathrm{x}$ & $\mathrm{x}$ \\
\hline & 1 & 1 & 1 & 0 & $\mathrm{x}$ & $\mathrm{x}$ & $\mathrm{x}$ \\
\hline & 1 & 1 & 1 & 1 & Tertutup & Terbuka & $\begin{array}{c}\text { Kelebihan } \\
\text { Air }\end{array}$ \\
\hline
\end{tabular}

Keterangan :

$0=$ kondisi sensor tidak terhubungdengan air

$1=$ kondisi sensor terhubung dengan air

$\mathrm{X}=$ error/ tidak beroprasi dengan baik

Terdapat 4 mode yang digunakan sebagai acuan untuk pengontrolan kondisi lahan sawah secara otomatis sesuai pada bagian 4.4 diatas. Selain mode tersebut, dapat dilakukan pengontrolan secara manual. Pengontrolan secara manual yaitu pengontrolan yang dilakukan oleh petani terhadap lahan persawahan dengan mengunjungi lahan sawah untuk melakukan proses buka tutup pintu air sawah sesuai dengan perspektif dari petani itu sendiri.

Pengontrolan ini dilakukan dengan cara menon-aktifkan alat kendali pintu air sawah otomatis yang digunakan pada lahan persawahan, dengan tidak aktifnya alat yang terpasang sehingga petani dapat melakukan pengontrolan lahan sawah secara manual baik dalam hal membuka atau menutup pintu sawah yang ada.

\section{Kesimpulan dan Saran}

\section{Kesimpulan}

Pada penelitian ini telah dibuat sebuah model kendali pintu air sawah otomatis dengan SIM800L berbasis mikrokontroler arduino uno. Sistem kerja alat ini mampu melakukan buka tutup pintu air pada lahan sawah secara otomatis serta memberikan informasi ketinggian air dengan bantuan sensor water level dan informasi tersebut akan dikirimkan melalui sms kepada petani. 
Penelitian ini menggunakan 4 mode input sebagai acuan dalam pengoprasian alat yang diantaranya yaitu, mode pengolahan digunakan sebagai acuan level air dalam proses pengolahan lahan sawah, mode penanaman digunakan sebagai acuan level air dalam melakukan proses penanaman padi pada lahan persawahan, mode normal digunakan sebagai acuan level air yang cukup untuk tananam melakukan proses fotosintesis dan mode pupuk digunakan sebagai acuan level air untuk melakukan proses pemupukan tanaman padi. Selain mode tersebut, dapat dilakukan pengontrolan pintu air secara manual dengan cara mematikan alat kendali pintu air otomatis yang digunakan pada lahan pertanian.

\section{Saran}

a. Penelitian ini masih menggunakan satu pintu input dan satu pintu output untuk irigasi, sehingga kedepan dapat dikembangkan menggunakan pintu yang bekerja baik sebagai input maupun output air dari irigasi.

b. Dengan mempertimbangkan adanya kemungkinan terjadinya gangguan listrik, penelitian ini dapat dikembangkan dengan menggunakan catu daya mandiri sehingga alat dapat beroperasi dengan baik.

\section{Daftar Pustaka}

Afrina, Mira.Dkk. 2015, Pengembangan Sistem Informasi SMS Gateway Dalam Meningkatkan Layanan Komunikasi Sekitar Akademika Fakultas IImu Komputer Unsri. Jurnal Sistem Informasi (JSI), VOL. 7, NO. 2, Oktober 2015. Universitas Sriwijaya.

Nif'an, Ahmad. 2016. Purwarupa Kendali Kanal Irigasi Sawah Terjadwal Berbasis Mikrokontroler ATmega328. Artikel keteknikan, Fakultas Teknik Universitas PGRI Yogyakarta.

Anisa,Ona. 2017. Rancang Bangun Pengukur Kadar Gas Metana Pada Lahan Gambut Menggunakan Sms gateway Dan Sensor MQ4 berbasis Mikrokontroler. Politeknik Negeri Sriwijaya, Palembang.

Azwir.,Ridwan, 2009. Peningkatan Produktivitas Padi Sawah Dengan Perbaikan Teknologi Budidaya. Jurnal Akta Agrosia Vol.12 No. 2 hlm 212-218 Juli-Des 2009.

Cahyo,Andi Dwi.2011. Analisis Unjuk Kerja Pengontrolan Tinggi Muka Air Pada Sistem Irigasi Otomatis Menggunakan Perangkat Berbasis Mikrokontroler. Skripsi, Institut Pertanian Bogor 11:13

Dhan, P. 2014. ATMega328 http://roboticsuniversity.com/2015/03/analog-todigitalconverter-adc-mikrokontroler-avr-atmega32.html 18 juli 2017. 
Dzulkifli S, M. Rivai,M dan Suwito. 2016. Rancang Bangun Sistem Irigasi Tanaman Otomatis Menggunakan Wireless Sensor Network. Jurnal Teknik ITS Vol. 5, No. 2.

Faiz Abdurrahman Hanur, Muhammad . 2016.[Skripsi] Rancang bangun alat pemutus kwh meter sebagai proteksi berbasis arduino. Teknik Elektro, Digital Repository Universitas Jember, halaman 7:8.

(Kho, Dickson. 2013. http://teknikelektronika.com/penger tian-relay-fungsi-relay/, 26 April 2016).

Mulyana,Eka.,Rindi Kharisman. 2014. Perancangan Alat Peringatan Dini Bahaya Banjir dengan Mikrokontroler Arduino Uno R3. Citec Journal, Vol. 1, No. 3, Mei 2014 Juli 2014.

Mufida,Elly.,Supriyanto, 2017. Otomatisasi Irigasi Sawah Menggunakan Sensor Elktroda Level Berbasis Mikrokontroler Atmega8535. Jurnal Teknik Komputer Amik Bsi Vol. III, No. 1, Februari 2017.

Motor Servo, http://rezaa.blog.pcr.ac.id/2017/05/21/module-14-intriductionarduino-group-9/ ( diakses pada 16 Agustus 2017)

Pramudita,Dimas. 2017. Protoype Sistem Buka Tutup Pintu Air Otomatis Pada Persawahan Berbasis Arduino Uno. Publikasi IImiah. Universitas Muhammadiyah Surakarta.

Priska Sari,Tia. Darwison. Ratna Aisuwarya. 2015. Sistem Monitoring Denyut Jantung Menggunakan Mikrokontroler Arduino Dan Komunikasi Modul Xbee. Jurusan Sistem Komputer, Fakultas Teknologi Informasi, Universitas Andalas, Padang.

Purwanto M.Y.J, Badrudin U. 1999. Fluktuasi kelembapan tanah pada budidaya gogorancak. Buletin Keteknian Pertanian 13 (1):1-8.

Peraturan Pemerintah Republik Indonesia Nomor 20 Tahun 2006. Tentang Irigasi(http://jdihn.bphn.go.id/?page=peraturan\&section=produk bphn\&act=searc h).

Rasidin. 2001. Rancangan Sistem Pengendali Tinggi Air [ Skripsi ]. Fakultas Teknologi Pertanian, Institut Pertanian Bogor.

Ramakumbo,Ario Gusti. 2012. Magnetic Door Lock Menggunakan Kode Pengaman Berbasis Atmega 328. Skripsi pendidikan Teknik Elektro Universitas Negeri Yogyakarta.

Ridwan,Wrastawa.2016. Modul Praktikum Mikrokontroler Dan Sensor. Teknik Elektro, Universitas Negeri Gorontalo.

Rusmanadi,Dedy. 2009. Mengenal Teknik Elektronika. Bandung. CV.Pionir Jaya 
Sagita, Mella. 2015. Aplikasi Led Rgb Pada Lengan Robot Penyortir Kotak Berdasarkan Warna Berbasis Arduino Uno. Teknik Elektronika, Politeknik Negeri Sriwijaya, Palembang.

Sari, Iskandar. 2017. Prototype shower otomatis Menggunakan Sensor Gerak (Pir) Dan Sensor Suara (Analog Sound Sensor). Teknik Elektro. Politeknik Negeri Padang.

Susanto,Heri. 2013. Perancangan Sistem Telemetri Wireless Untuk Mengukur Suhu Dan Kelembaban Berbasis Arduino Uno R3 Atmega328p Dan Xbee Pro. Jurnal, Universitas Maritim Raja Ali Haji. Teknik Elektro.

Sucitra, T. (2016). ATmega328. https://trisnote.blogspot.co.id/201511/ atmega328.html. 18 juli 2017.

Syahrul.2011. Karakteristik Dan pengontrolanServomotor. Bandung : Majalah IImiah Unikom. Vol 8 (2), 143-150.

Tim Arduino, http://www.arduino.cc/en/Guide/Introduction (diakses pada 24 November 2017).

Winarbawa S. 2000. Pegaruh kadar air tanah terhadap pertumbuhan dan produksi dua tipe kapolaga sabrang. Buletin Agronomi. 28(1):1-8.

Zulkham,Umar Rosyidin. 2017. [Skripsi] Perancangan Alat Kendali Irigasi Sawah Menggunakan Short Message Service (Sms) Berbasis Mikrokontroler Atmega 16. 